\title{
Removal of Aluminum from Water Samples by Sorption onto Powdered Activated Carbon Prepared from Olive Stones
}

\author{
S. E. Ghazy ${ }^{\wedge}$ and S. M. El-Morsy \\ Chemistry Department, Faculty of Science, Mansoura University, P.O. Box, 66 Mansoura, Egypt \\ ‘e-mail: ghazyse@mans.edu.eg \\ (Received July 23, 2007; Accepted September 17, 2007)
}

\begin{abstract}
Recent studies have revealed the poisonous nature of aluminum(III) species to aquatic and terrestrial organisms. Therefore, this investigation aims to develop batch adsorption experiments in the laboratory, aiming to the removal of aluminum(III) from aqueous solutions onto powdered activated carbon (PAC). The latter (which is an effective and inexpensive sorbent) was prepared from olive stones generated as plant wastes and modified with an aqueous modifying oxidizing agent, viz. $\mathrm{HNO}_{3}$. The main parameters (i.e. initial solution $\mathrm{pH}$, sorbent and $\mathrm{Al}^{3+}$ ions concentrations, stirring times and temperature) influencing the sorption process were examined. The results obtained revealed that the sorption of $\mathrm{Al}^{3+}$ ions onto PAC is endothermic in nature and follows first-order kinetics. The adsorption data were well described by the Langmuir, Freundlich and DubininRadushkevich (D-R) adsorption models over the concentration range studied. Under the optimum experimental conditions employed, the removal of ca. $100 \% \mathrm{Al}^{3+}$ ions in the concentration range $1.35-2.75 \mathrm{mg} \cdot \mathrm{l}^{-1}$ was attained. Moreover, the procedure was successfully applied to the recovery of aluminum spiked to some environmental water samples with an RSD (\%), does not exceed $1.22 \%$.
\end{abstract}

Keywords : Aluminum, Sorption, Activated carbon, Water samples, Natural waters

\section{Introduction}

Trace elements, especially toxic metals, are considered to be one of the main sources of pollution in the environment, since they have a significant effect on its ecological quality. Human activities often mobilize and redistribute natural substances in the environment so much so that they can cause adverse effects. Otherwise, high levels of toxic metals in sediments, sludge and soils, and through transfer processes; also in groundwater and plants, may have a negative effect on animals and human health $[1,2]$.

Aluminum is the most abundant metal in the earth's crust, comprising approximately $7 \%$ of the matter in average soil, after oxygen and silicon. In the industrialized world this metal is second only to iron in its usage and its compounds can justifiably be said to touch our lives daily [3-5]. The toxicity of aluminum towards organisms of terrestrial and aquatic habitats is well known [6-11] and it depends primarily on its specific forms $[12,13]$. Labile positively charged monomeric forms of aluminum $\left(\mathrm{Al}^{3+}, \mathrm{Al}(\mathrm{OH})^{2+}\right.$ and $\mathrm{Al}(\mathrm{OH})_{2}{ }^{+}$have been recognized as the most toxic aluminum species [13,14]. Moreover, these aluminum species are associated to several diseases as renal insufficiency, encephalopathy, pulmonary fibrosis, microcytic anemia and disturbances of the sleeping. Bearers of Alzheimer's diseases present high concentrations of aluminum in the brain [15].
Aluminum is still used as a flocculating agent in potable water treatment units and hence there is a strong need for aluminum monitoring in treated and raw waters $[11,16]$. Because of the potential risks of aluminum, European Community legislation on the quality of water for human consumption sets a MAC (maximum admissible concentration) level of $200 \mathrm{ng} \cdot \mathrm{ml}^{-1}$ and a guide-line level, around which Member states should set their quality standards of 50 $\mathrm{ng} \cdot \mathrm{ml}^{-1}$ [11]. Therefore, investigations must be directed to the development of methods for the removal of toxic aluminum species.

Different Physico-chemical processes in use for heavymetal removal from wastewater include precipitation, coagulation, reduction process, ion exchange, membrane processes (such as ultra-filtration, electro-dialysis and reverse osmosis) and adsorption [17]. Of these adsorption onto powdered activated carbon (PAC) has proved to be a very effective technique for the removal of low concentrations of organic compounds and inorganic toxic species from water supplies and wastewaters owing to its high efficiency and removal capacity [18-22]. PAC is usually considered the sorbent against which others are assessed [19]. It has the advantage of being less costly to manufacture, offering more surface area for adsorption, high efficiency and removal capacity and distributing more easily and uniformly in water [22]. It also offers the advantage that the dose and reaction time can 
be adjusted according to the composition of the liquid streams to be treated [21]. Moreover, PAC requires minimal capital expenditure for feeding and contacting equipment [18].

Since no data are available in the literature concerning the use of PAC as a sorbent for aluminum, the objective of the present work was to study the possibility of using PAC prepared from olive stones (which is an effective and inexpensive sorbent) for removing aluminum ions from aqueous solutions. The different parameters influencing the adsorption of aluminum ions onto powdered activated carbon were optimized and the results are presented in this paper.

\section{Experimental}

\subsection{Materials}

Modified powdered activated carbon was prepared from olive stones after washing with $5 \%$ aqueous solution of $\mathrm{HCl}$, followed several times by distilled water and drying at $125^{\circ} \mathrm{C}$, and then subjected to destructive distillation for $5 \mathrm{~h}$ at $600^{\circ} \mathrm{C}$ under a flow of nitrogen. The resulting material was subsequently activated by gasification with steam at $900^{\circ} \mathrm{C}$. The modified activated carbon sample was prepared by treatment with conc. $\mathrm{HNO}_{3}\left(10 \mathrm{ml} \cdot \mathrm{g}^{-1}\right.$ carbon $)$. The suspension was shaken for $48 \mathrm{~h}$ at room temperature, after which the modified activated carbon sample was removed by filtration, washed with distilled water and dried in an air oven for $24 \mathrm{~h}$ at $125^{\circ} \mathrm{C}$. Whilst hot, the treated carbon sample was then quickly transferred to a desiccator and subjected to low-pressure evacuation. A mean particle size of ca. $12 \mathrm{~mm}$ was employed in subsequent experiments. Experimental characterization of the carbon sample under

Table 1. Characterization of modified activated carbon sample (PAC)

\begin{tabular}{|c|c|}
\hline Type of characterization & PAC \\
\hline Ash content $(\%)$ & 6.3 \\
\hline Surface area $\left(\mathrm{m}^{2} / \mathrm{g}\right)$ by BET equation & 250.1 \\
\hline The total pore volume $\mathrm{V}_{\mathrm{T}}(\mathrm{ml} / \mathrm{g})$ & 0.68 \\
\hline The mean pore radius $r_{m}(n m)$ & 2.22 \\
\hline Mean particle size $(\mu \mathrm{m})$ & 12.0 \\
\hline $\begin{array}{l}\text { Suspension } \mathrm{pH} \text { after } 4 \mathrm{~h} \text { stirring } \\
\text { (distilled water } \mathrm{pH}=6.8 \text { ) }\end{array}$ & 8.2 \\
\hline \multicolumn{2}{|l|}{$\begin{array}{l}\text { Base neutralization capacities } \\
\text { (mg equiv/g) }\end{array}$} \\
\hline $\mathrm{NaHCO}_{3}$ & 0.10 \\
\hline $\mathrm{Na}_{2} \mathrm{CO}_{3}$ & 0.16 \\
\hline $\mathrm{NaOH}$ & 0.18 \\
\hline \multicolumn{2}{|l|}{ IR bands $\left(\mathrm{cm}^{-1}\right)$} \\
\hline$v(\mathrm{COOH})$ & 1383 \\
\hline$v(\mathrm{OH})$ & $3400-3450$ \\
\hline
\end{tabular}

investigation (Table 1) revealed that: the surface area of PAC is $250.1 \mathrm{~m}^{2} / \mathrm{g}$ (employing the conventional BET equation), its total pore volume $\left(\mathrm{V}_{\mathrm{T}}\right)$ is $0.68 \mathrm{ml} / \mathrm{g}$, its mean pore radius $\left(\mathrm{r}_{\mathrm{m}}\right)$ is $2.22 \mathrm{~nm}$, its ash content is $6.3 \%$ and its suspension $\mathrm{pH}$ after $4 \mathrm{~h}$ stirring (water $\mathrm{pH}=6.8$ ) is 8.2 . The base neutralization capacities (m equiv. ${ }^{-1}$ ) for $\mathrm{NaHCO}_{3}, \mathrm{Na}_{2} \mathrm{CO}_{3}$ and $\mathrm{NaOH}$ are $0.10,0.16$ and 0.18 , respectively. Moreover, the IR analysis of PAC sample revealed the appearance of two absorption bands at $1383 \mathrm{~cm}^{-1}$ and $3400-3450 \mathrm{~cm}^{-1}$ assigned to $v(\mathrm{COOH})$ and $v(\mathrm{OH})$, respectively.

\subsection{Reagents}

All the solutions were prepared from certified reagentgrade chemicals. Aluminum stock solution $\left(1 \mathrm{mg} \cdot \mathrm{ml}^{-1}\right)$ was prepared from $\mathrm{AlK}\left(\mathrm{SO}_{4}\right)_{2} \cdot 12 \mathrm{H}_{2} \mathrm{O}(\mathrm{BDH} \mathrm{Ltd}$, Poole, England) by dissolving $17.59 \mathrm{~g}$ in doubly distilled water containing 5 $\mathrm{ml}$ of concentrated $\mathrm{H}_{2} \mathrm{SO}_{4}$, and diluting to 1 liter. Chrome Azurol S (CAS) and 1\% ascorbic acid were freshly prepared. Aqueous solutions of $\mathrm{HCl}$ and $\mathrm{NaOH}$ were used for $\mathrm{pH}$ adjustments. Further dilutions were prepared daily as required.

\subsection{Apparatus}

Spectrophotometric measurements were carried out using a Unicam UV2-100 UV/Visible Spectrophotometer v3.32 with $1 \mathrm{~cm}$ glass cells. Sometimes the data were recorded using a Griffin Model 40 Colorimeter. The infrared analyses were undertaken via a Mattson 5000 FT-IR spectrophotometer using the $\mathrm{KBr}$ disc method. The stirring of solutions was performed with a magnetic stirrer Model VEHP, Sientifica, Italy. The $\mathrm{pH}$ was measured using Jeanway 3310 $\mathrm{pH}$ meter.

\subsection{Methods}

Unless stated otherwise, all batch sorption experiments were conducted at room temperature (ca. $\sim 25^{\circ} \mathrm{C}$ ). Known volumes of aluminum ion solutions were pipetted into quickfit glass bottles containing $0.2 \mathrm{~g}$ of PAC sorbent in 100 $\mathrm{ml}$ of aqueous solution to give initial concentrations ranging from 1.35 to $8.1 \mathrm{mg} \cdot \mathrm{l}^{-1}$. Since the $\mathrm{pH}$ of the resulting solution was ca. 7 , no further control of $\mathrm{pH}$ was necessary since it was suitable for most adsorption experiments. The resulting solutions were then stirred with a magnetic stirrer (VELP, Scientifica, Italy) at $200 \mathrm{rpm}$ and the samples taken at fixed times $(1,2,3,4,5,10,15,20,25,30, \ldots$ and 120 min) to enable a study of the kinetics of the adsorption process. In other studies, equilibrium was attained after stirring for known time (ca. $20 \mathrm{~min}$ ). Preliminary experiments showed that this time length was sufficient for adsorption of $\mathrm{Al}(\mathrm{III})$ onto PAC. The samples were subsequently filtered and the residual $\mathrm{Al}^{3+}$ ion content in the filtrate was analyzed 
spectrophotometerically using CAS at $545 \mathrm{~nm}$. The percentage adsorption of $\mathrm{Al}^{3+}$ ions from solution was calculated from the relationship:

$$
\% \text { Adsorption }=\left(\mathrm{C}_{\mathrm{i}}-\mathrm{C}_{\mathrm{f}}\right) / \mathrm{C}_{\mathrm{i}} \times 100
$$

where $\mathrm{C}_{\mathrm{i}}$ is the initial concentration of $\mathrm{Al}^{3+}$ ions and $\mathrm{C}_{\mathrm{f}}$ is the residual concentration after equilibration. The metal uptake $\mathrm{q}$ $\left(\mathrm{mg} \cdot \mathrm{g}^{-1}\right)$ was calculated as:

$$
\mathrm{q}=\left[\left(\mathrm{C}_{\mathrm{i}}-\mathrm{C}_{\mathrm{f}}\right) / \mathrm{m}\right] \cdot \mathrm{V}
$$

where $\mathrm{m}$ is the quantity of adsorbent $(\mathrm{mg})$ and $\mathrm{V}$ is the volume of the suspension (ml). To asses the applicability of the procedure, another series of experiments was conducted on $1 \mathrm{~L}$ suspensions of clear and pre-filtered natural water samples with an initial $\mathrm{pH}$ adjusted to 7. These suspensions were placed in a $2 \mathrm{~L}$ glass beaker containing 1.35 or $2.75 \mathrm{mg}$ $\mathrm{Al}^{3+}$ ions and $200 \mathrm{mg} \cdot \mathrm{L}^{-1}$ of $\mathrm{PAC}$ at $25^{\circ} \mathrm{C}$ and stirred magnetically for $20 \mathrm{~min}$ at $200 \mathrm{rpm}$.

\section{Results and Discussion}

Preliminary experiments using commercially activated charcoal, as a commercially activated carbon, for the sorption of aluminum from aqueous solution were carried out. The results showed low adsorption which does not exceed $70 \%$. Moreover, conventional and commercially activated carbons are expensive [23] and have low selectivity and adsorptive capacity towards heavy metals [24]. This has motivated us to use low-cost, readily available agricultural solid waste (ca. olive stones) after activation and modification for the removal of aluminum ions from aqueous solution. The utilization of such material as a sorbent in the adsorption process has the additional advantage of providing a method for its disposal [23].

\subsection{Kinetics of the Adsorption Process}

Fig. 1 shows the variation in the percentage adsorption (removal) of aluminum ions onto PAC sorbent with stirring time, at various initial metal ion concentrations. The data depicted in this figure indicate that the adsorption of aluminum ions is quite rapid over the first stage of the process which may indicate that adsorption occurred mainly at the surface of the solid and to some extent by the internal pores $[25,26]$. However, with the passage of time the rate of adsorption decreased and reached a constant value (equilibrium time). This slow adsorption during the second stage may be due to the diffusion of aluminum ions into the pores of solid sorbent $[26,27]$. The time necessary to reach such adsorption equilibrium was found to be 2.0 and $14 \mathrm{~min}$ for initial concentrations of $1.35,2.70 \mathrm{mg} \cdot \mathrm{L}^{-1} \mathrm{Al}^{3+}$ ions, respectively and $20 \mathrm{~min}$ for those of 4.05, 5.40, 6.75 and 8.10 $\mathrm{mg} \cdot \mathrm{L}^{-1} \mathrm{Al}^{3+}$ ions. Hence, to ensure that adsorption had

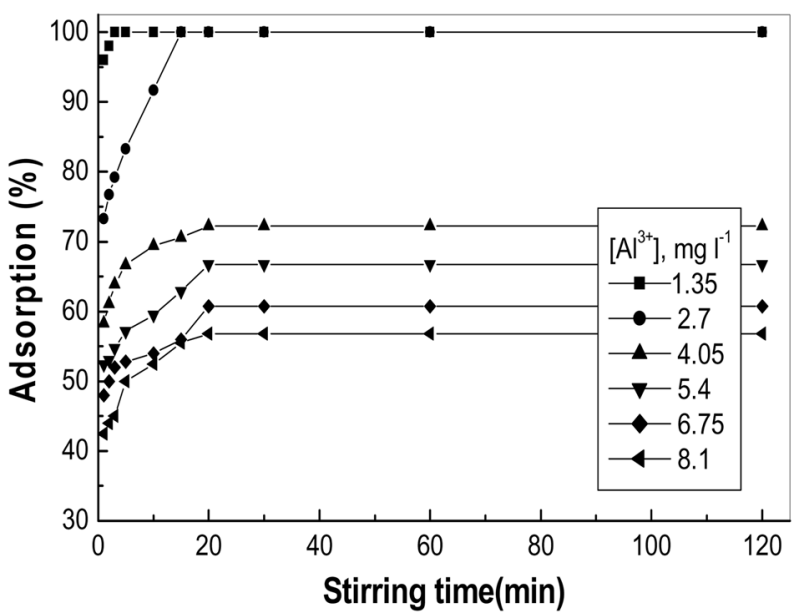

Fig. 1. Influence of stirring time on the adsorption of various concentrations of $\mathrm{Al}^{3+}$ ions by PAC $\left(200 \mathrm{mg} \cdot \mathrm{L}^{-1}\right)$ at $\mathrm{pH} 7$.

reached equilibrium in all cases, a stirring time of $20 \mathrm{~min}$ was selected for all samples studied. The results also indicated that the percentage removal of metal ion from the solution decreases with increasing initial metal ion concentration. This can be explained by a decrease in the number of adsorption sites having an affinity towards $\mathrm{Al}^{3+}$ ions.

An interesting series of experiments was carried out to evaluate the effect of soaking time (i.e. without stirring) on the removal rate of $2.7,5.4,6.75$ and $8.1 \mathrm{mg} \cdot \mathrm{L}^{-1}$ of $\mathrm{Al}^{3+}$ ions using $200 \mathrm{mg} / \mathrm{l}$ PAC sorbent. The results obtained revealed that a maximum removal rate of $\mathrm{Al}^{3+}$ ions (ca. 100\%) was attained after soaking for $\geq 60 \mathrm{~min}$. These results may be useful from an economic viewpoint of industrial wastewater treatment.

When the results depicted in Fig. 1 were re-plotted against the square root of the stirring time, linear correlations were obtained (Fig. 2) which may verify the Morris-Weber equation [28]:

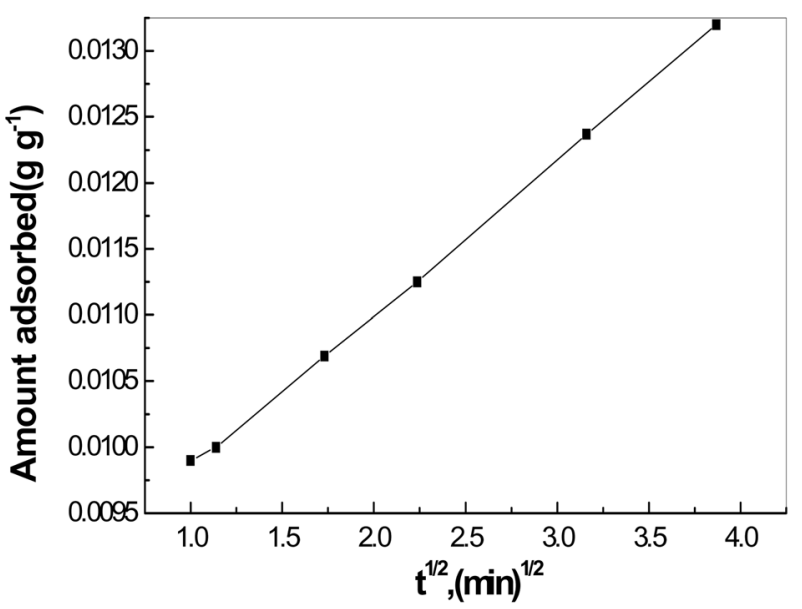

Fig. 2. Plot of the amount of $\mathrm{Al}^{3+}$ ions adsorbed onto PMW $\left(100 \mathrm{mg} \cdot \mathrm{L}^{-1}\right)$ versus square root of time at $\mathrm{pH} 7$. 


$$
\mathrm{X}=\mathrm{K}_{\mathrm{d}}(\mathrm{t})^{1 / 2}
$$

where $\mathrm{X}$ is the amount of $\mathrm{Al}^{3+}$ ions adsorbed $\left(\mathrm{g} \cdot \mathrm{g}^{-1}\right)$. This indicates that an intrapore diffusion mechanism was involved in adsorption of $\mathrm{Al}^{3+}$ ions by PAC (Fig. 1). Fig. 2 shows that two distinct regions were observed: an initial linear portion which is due to the boundary layer diffusion effect [29] and a second portion which is due to the intraparticle diffusion effect [30]. However, the fact that the line depicted in Fig. 2 does not pass through the origin indicates that intrapore diffusion is not the controlling step in sorption of $\mathrm{Pb}^{2+}$ ions by PAC $[25,28]$. These data agree with those of Juang et al. [31] who proposed that the first sharp portion of the curve should be attributed to adsorption on the external surface of the sorbent while the second gradual portion should be attributed to intrapore diffusion. The calculated value of the rate constant for intrapore diffusion $\mathrm{K}_{\mathrm{d}}$ is $1.16 \times$ $10^{-3}\left(\mathrm{~g} / \mathrm{g} \mathrm{min}{ }^{1 / 2}\right)$.

Again the kinetic data (Fig. 1) of the adsorption of $\mathrm{Al}^{3+}$ ions on to PAC was checked via the Bangham equation [32]:

$$
\log \log \left[\mathrm{C}_{\mathrm{o}} /\left(\mathrm{C}_{\mathrm{o}}-\mathrm{XW}\right)\right]=\log \left(\mathrm{K}_{\mathrm{o}} \mathrm{W} / 2.303 \mathrm{~V}\right)+\mathrm{a} \log \mathrm{t}
$$

where $\mathrm{X}$ and $\mathrm{V}$ have been defined above, $\mathrm{C}_{\mathrm{o}}$ is the initial concentration of $\mathrm{Al}^{3+}$ ions $\left(\mu \mathrm{g} \cdot \mathrm{mL}^{-1}\right), \mathrm{W}$ is the amount of PAC $(\mathrm{g}), \mathrm{t}$ is the time (min), $\alpha$ is the Bangham equation constant (its value being usually $<1$ ) and $\mathrm{K}_{\mathrm{o}}$ is a proportionality constant. Plot of $\log \log \left[\mathrm{C}_{\mathrm{o}} /\left(\mathrm{C}_{\mathrm{o}}-\mathrm{XW}\right)\right]$ versus $\log \mathrm{t}$ gave straight line deviated lastly (Fig. 3). These results show that the diffusion of $\mathrm{Al}^{3+}$ ions into the pores of PAC played an important role in the adsorption process. These results were similar to those described elsewhere [27, 33]. The calculated values of $\alpha$ and $K_{o}$ are 0.07 and 0.366 , respectively.

The kinetic data depicted in Fig. 1 for $\mathrm{Al}^{3+}$ ion adsorption by PAC were tested using Lagergren equation, as cited by Gupta and Shukla [34]:

$$
\log \left(\mathrm{X}_{\mathrm{e}}-\mathrm{X}\right)-\log \mathrm{X}_{\mathrm{e}}=-\mathrm{K}_{\mathrm{ads}} \mathrm{t} / 2.303
$$

where $\mathrm{X}_{\mathrm{e}}$ is the amount of $\mathrm{Al}^{3+}$ ions adsorbed at equilibrium

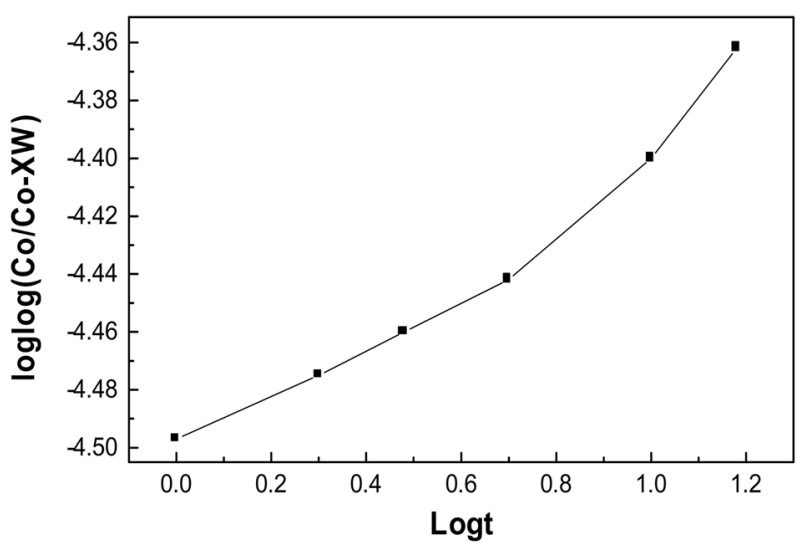

Fig. 3. Plot of $\log \log \left[\mathrm{C}_{\mathrm{o}} /\left(\mathrm{C}_{\mathrm{o}}-\mathrm{XW}\right)\right]$ versus $\log \mathrm{t}$ for the adsorption of $\mathrm{Al}^{3+}$ ions $\left(2.7 \mathrm{mg} \cdot \mathrm{L}^{-1}\right)$ by PAC $\left(200 \mathrm{mg} \cdot \mathrm{L}^{-1}\right)$ at $\mathrm{pH} 7$.

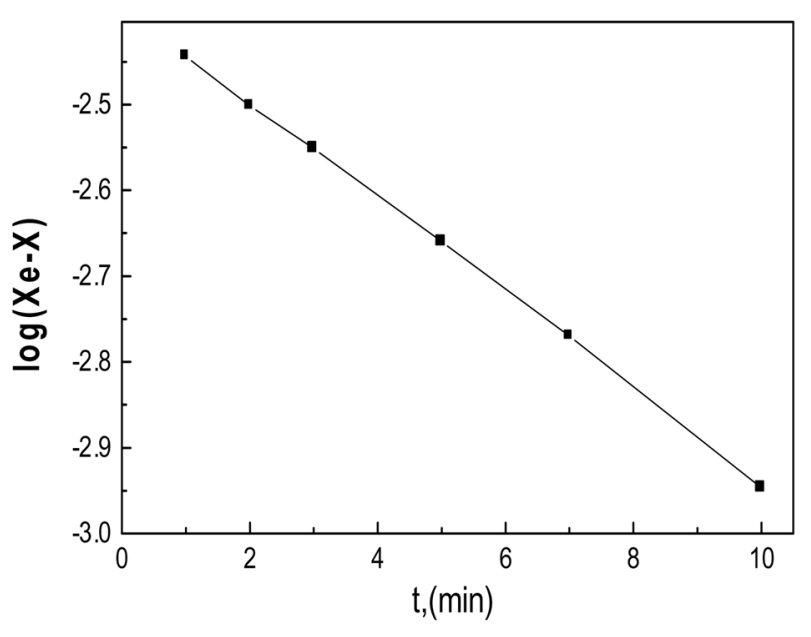

Fig. 4. Plot of $\log \left(\mathrm{X}_{\mathrm{e}}-\mathrm{X}\right)$ versus stirring time for $\mathrm{Al}^{3+}$ ions $(2.7$ $\left.\mathrm{mg} \cdot \mathrm{L}^{-1}\right)$ adsorption onto PAC $\left(200 \mathrm{mg} \cdot \mathrm{L}^{-1}\right)$.

$(\mathrm{g} / \mathrm{g}), \mathrm{K}_{\mathrm{ads}}$. is the first-order rate constant for $\mathrm{Al}^{3+}$ ions adsorption onto PAC $\left(\mathrm{min}^{-1}\right), \mathrm{X}$ and $\mathrm{t}$ have been defined previously. The linear plots of $\log \left(\mathrm{X}_{\mathrm{e}}-\mathrm{X}\right)$ versus $\mathrm{t}$ obtained (Fig. 4) show the appropriateness of the above equation and consequently the first-order nature of the process involved. The calculated value of $\mathrm{K}_{\text {ads. }}$ was $0.127 \mathrm{~min}^{-1}$.

\subsection{Effect of pH value}

The influence of variation of $\mathrm{pH}$ values on $\mathrm{Al}^{3+}$ ions adsorption by PAC is shown by the data depicted in Fig. 5 . These data show that the removal of $\mathrm{Al}^{3+}$ ions increased as the $\mathrm{pH}$ of the suspension increased. It should be noted that the removal of trivalent aluminum by PAC sorbent is influenced by the surface properties of PAC and aluminum species present in aqueous solution.

At $\mathrm{pH}<3$, aluminum may be present as $\mathrm{Al}^{3+}$ and the hydrolytic species (ca. $\mathrm{Al}(\mathrm{OH})^{2+}$ and $\mathrm{Al}(\mathrm{OH})_{2}{ }^{+}$). Moreover,

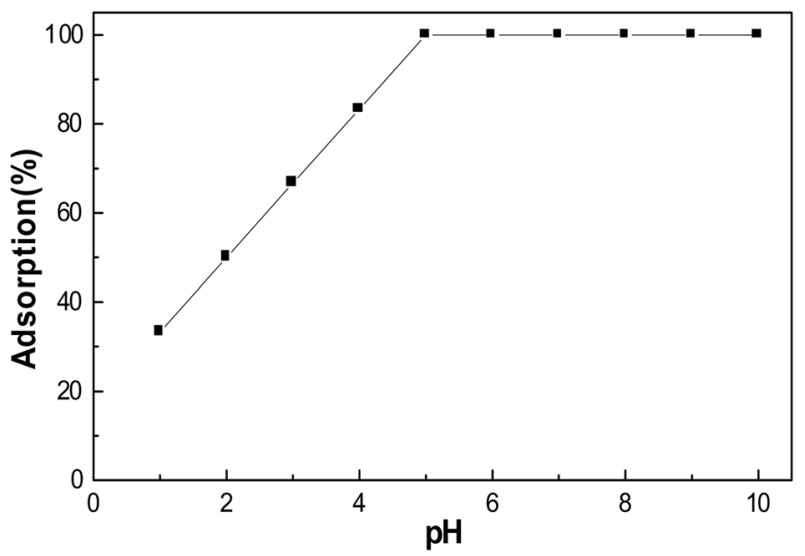

Fig. 5. Adsorption of $\mathrm{Al}^{3+}$ ions $\left(2.7 \mathrm{mg} \cdot \mathrm{L}^{-1}\right)$ by $\mathrm{PAC}(200$ $\mathrm{mg} \cdot \mathrm{L}^{-1}$ ) versus $\mathrm{pH}$. 
the oxo groups $\left(\mathrm{C}_{\mathrm{x}} \mathrm{O}\right.$ and $\left.\mathrm{C}_{\mathrm{x}} \mathrm{O}_{2}\right)$ formed on the surface of active carbon during its activation react with water according to the following reaction [19]:

$$
\mathrm{C}_{\mathrm{x}} \mathrm{O}_{2}+\mathrm{H}_{2} \mathrm{O} \rightarrow \mathrm{C}_{\mathrm{x}} \mathrm{O}^{2+}+2 \mathrm{OH}^{-}
$$

forming positively charged groups; thereby hindering the adsorption of $\mathrm{Al}^{3+}$ ions and the hydrolytic species. Therefore, the removal of $\mathrm{Al}^{3+}$ ions is small $\leq 50 \%$. Since PAC is alkaline in nature, (the $\mathrm{pH}$ of its suspension was always raised after its stirring for some time when the system was not buffered) $100 \%$ removal of $\mathrm{Al}^{3+}$ ions occurred in the $\mathrm{pH}$ range 5-9 via adsorption of hydrolytic species, via chemical interaction with the carboxylic groups of active carbon, and/ or precipitation of $\mathrm{Al}(\mathrm{OH})_{3}(\mathrm{~s})$.

In alkaline medium, at $\mathrm{pH}>9$, the removal of $\mathrm{Al}^{3+}$ ions decreases which may be attributed to the incapability of adsorption of the negative species, $\mathrm{Al}(\mathrm{OH})_{4}{ }^{-}$on the negative surface of PAC sorbent. Therefore, $\mathrm{pH} 7$ was recommended throughout all other experiments.

\subsection{Effect of the amount of sorbent}

The amount of PAC employed as the sorbent also influenced the efficiency of adsorption of $\mathrm{Al}^{3+}$ ions from aqueous solution. The results obtained in Fig. 6, showed that the adsorption efficiency increased as the amount of PAC in the system increased to reach a maximum value (ca. 100\%) at $\geq 150 \mathrm{mg} \cdot \mathrm{L}^{-1}$ of PAC. The reason for such behavior may be attributed to an increase in the number of binding sites on the sorbent surface available to the metal ions. For this reason, $200 \mathrm{mg} \cdot \mathrm{L}^{-1}$ of PAC were used in all subsequent experiments.

\subsection{Effect of metal ion concentration}

The effect aluminum ion concentration on the adsorption

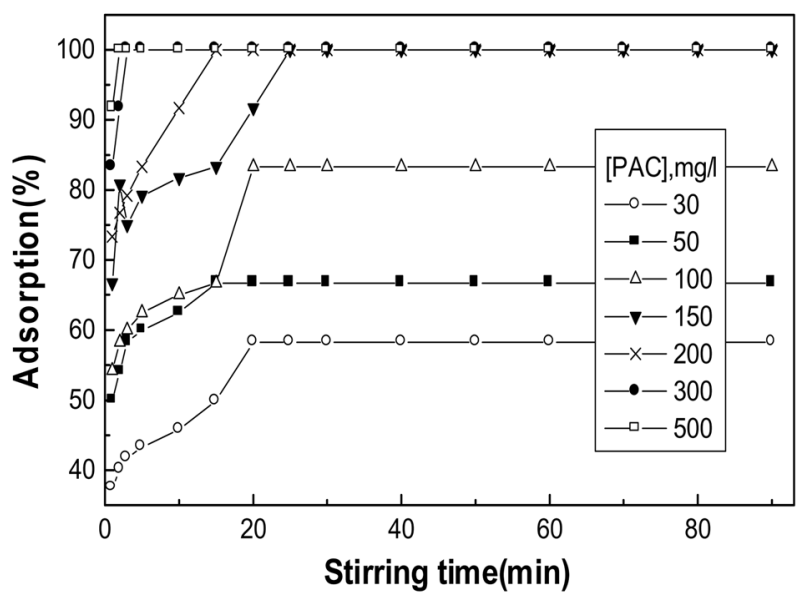

Fig. 6. Adsorption of $\mathrm{Al}^{3+}$ ions $(2.7 \mathrm{mg} / \mathrm{l})$ versus PAC concentrations at $\mathrm{pH} 7$ and various stirring times. process was investigated under the optimized conditions. The results obtained indicated that the adsorption of $\mathrm{Al}^{3+}$ ions was virtually constant (ca. $100 \%$ ) up to $8 \mathrm{mg} \cdot \mathrm{L}^{-1}$ of aluminum, beyond which the adsorption decreased. This may be explained in terms of the relatively smaller number of active sites available for higher $\mathrm{Al}^{3+}$ ion concentrations.

\subsection{Effect of temperature}

The effect of varying the temperature on the adsorption efficiency of various initial concentrations of aluminum is shown in Fig. 7. Close inspection of the figure showed that increasing of temperature from $5^{\circ}$ to $80^{\circ} \mathrm{C}$ plays two important functions. It increased both the efficiency of the adsorption and the amount of metal ions adsorbed on the same dose of sorbent. Such results may be attributed to an acceleration of some of the originally slow adsorption steps or to the creation of some new active sites on the adsorbent. In addition, the mobility of $\mathrm{Al}^{3+}$ ions from the bulk solution towards the adsorbent surface may be enhanced [35].

Such results could suggest that the adsorption of $\mathrm{Al}^{3+}$ ions involves chemical bond formation [28]. Accordingly, chelate formation may occur between $\mathrm{Al}^{3+}$ ions and oxygen atoms on PAC surface. Since most industrial effluents are usually hot, the simple adsorption procedure presented here may find application in industrial wastewater treatment for the removal of $\mathrm{Al}^{3+}$ ions.

\subsection{Adsorption isotherms}

To determine the capacity of PAC as a sorbent for $\mathrm{Al}^{3+}$ ions, three isotherm equations, i.e. the Freundlich, Langmuir and Dubinin-Radushkevich, were employed. The linearized form of the Freundlich equation may be written as:

$$
\ln \mathrm{q}_{\mathrm{e}}=\ln \mathrm{K}_{\mathrm{F}}+1 / \mathrm{n}\left(\ln \mathrm{C}_{\mathrm{e}}\right)
$$

where $\mathrm{q}_{\mathrm{e}}\left(\mathrm{mg} \cdot \mathrm{g}^{-1}\right)$ is the amount of $\mathrm{Al}^{3+}$ ion adsorbed, $\mathrm{C}_{\mathrm{e}}$

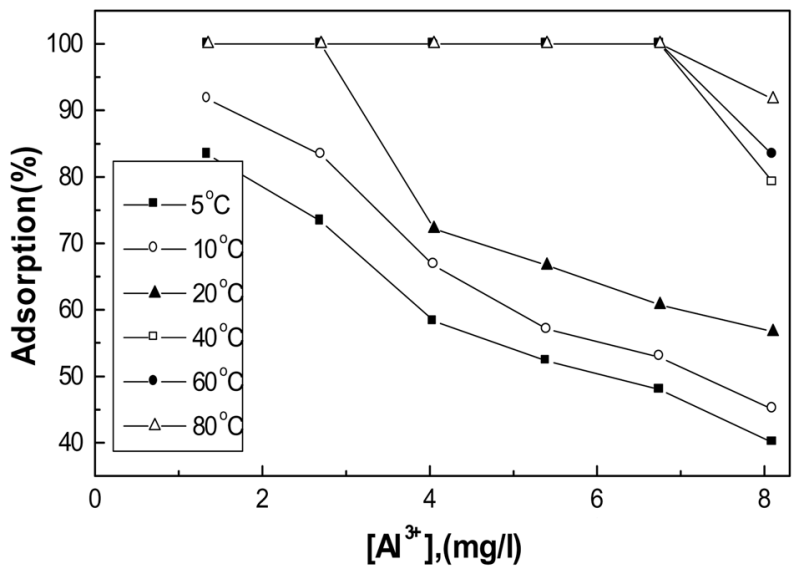

Fig. 7. Adsorption of different concentrations of $\mathrm{Al}^{3+}$ ion by PAC (200 $\left.\mathrm{mg} \cdot \mathrm{L}^{-1}\right)$ at various temperatures. 


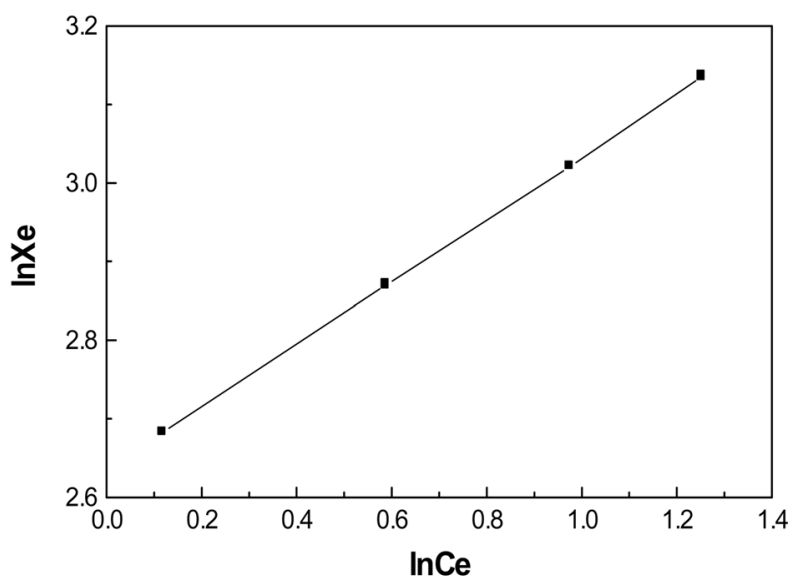

Fig. 8. Freundlich plot for $\mathrm{Al}^{3+}$ ion adsorption onto PAC.

$\left(\mathrm{mg} \cdot \mathrm{L}^{-1}\right)$ is its final equilibrium concentration and $\mathrm{n}$ and $\mathrm{K}_{\mathrm{F}}$ are the Freundlich equation parameters. This equation was applied to the experimental data depicted in Fig. 1 with a linear plot being obtained when $\ln \mathrm{q}_{\mathrm{e}}$ was plotted against $\ln$ $\mathrm{C}_{\mathrm{e}}$ (Fig. 8). This demonstrates the applicability of the Fruendich model to $\mathrm{Al}^{3+}$ ion adsorption onto PAC. The parameters $\mathrm{K}_{\mathrm{F}}$ and $\mathrm{n}$ for $\mathrm{Al}^{3+}$ ions adsorption have been calculated from the intercept and slope of the plot depicted in Fig. 8, giving values of 13.95 and 2.52, respectively with a correlation coefficient ( $r$ ) of 0.9999 . Favorable adsorption of $\mathrm{Al}^{3+}$ ions by PAC was demonstrated by the fact that the value of $n$ was greater than unity $[27,36]$. The linear form of the Langmuir equation applied to the aluminum ion adsorption data in Fig. 1 was:

$$
1 / \mathrm{q}_{\mathrm{e}}=\left(1 / \mathrm{K}_{\mathrm{L}} \mathrm{b}\right) \cdot 1 / \mathrm{C}_{\mathrm{e}}+1 / \mathrm{K}_{\mathrm{L}}
$$

where $\mathrm{K}_{\mathrm{L}}\left(\mathrm{mg} \cdot \mathrm{g}^{-1}\right)$ is the Langmuir constant and $\mathrm{b}\left(\mathrm{ml} \cdot \mathrm{mg}^{-1}\right)$ is the monolayer adsorption capacity. Fig. 9 showed that a plot of $1 / q_{e}$ versus $1 / C_{e}$ gave a straight line, thereby suggesting the applicability of the Langmuir model. This also demonstrated that monolayer coverage of aluminum ions

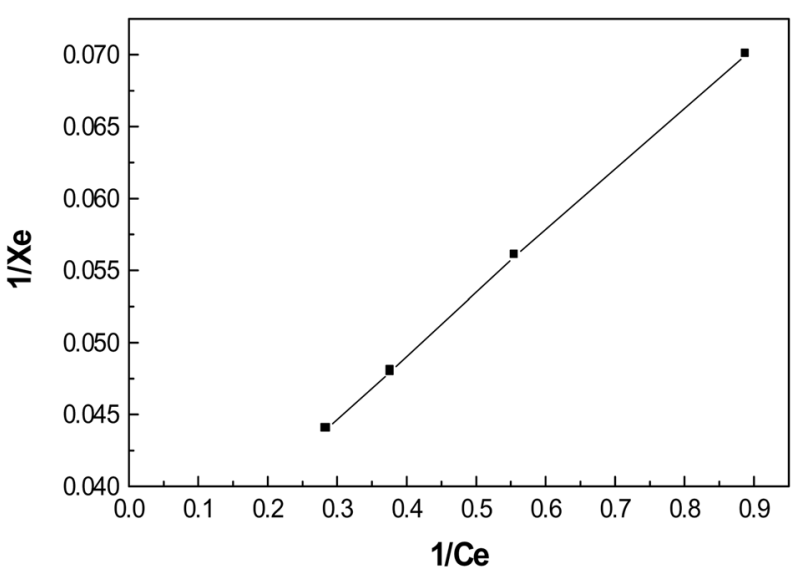

Fig. 9. Langmuir plot for $\mathrm{Al}^{3+}$ ions adsorption onto PAC. occurred on the outer surface of PAC [27, 37]. The values of $\mathrm{K}_{\mathrm{L}}$, b and the correlation coefficient $(\mathrm{r})$ are $31.43 \mathrm{mg} \cdot \mathrm{g}^{-1}$, $0.739 \mathrm{ml} \cdot \mathrm{mg}^{-1}$ and 0.9999 , respectively.

The Gibbs free energy change, $\Delta \mathrm{G}(\mathrm{kJ} / \mathrm{mol})$, for adsorption of $\mathrm{Al}^{3+}$ ions by PAC can be calculated using the following thermodynamic equation [38]:

$$
\ln (1 / \mathrm{b})=-\Delta \mathrm{G} / \mathrm{RT}
$$

where $\mathrm{T}$ is the absolute temperature $(\mathrm{K})$ and $\mathrm{R}$ is a constant (8.3143 J.(K mol $)^{-1}$. The value of DG calculated at $298^{\circ} \mathrm{K}$ was found to be $-0.7495 \mathrm{~kJ} \cdot \mathrm{mol}^{-1}$. The negative sign for DG indicates the spontaneous nature of $\mathrm{Al}^{3+}$ ions adsorption onto PAC.

The Dubinin-Radushkevich (D-R) isotherm equation was also tested in its linearized form:

$$
\ln X=\ln X_{m}-\beta \varepsilon^{2}
$$

and

$$
\varepsilon=\mathrm{RT} \ln (1+1 / \mathrm{C})
$$

where $\mathrm{C}$ is the liquid-phase concentration of $\mathrm{Al}^{3+}$ ions

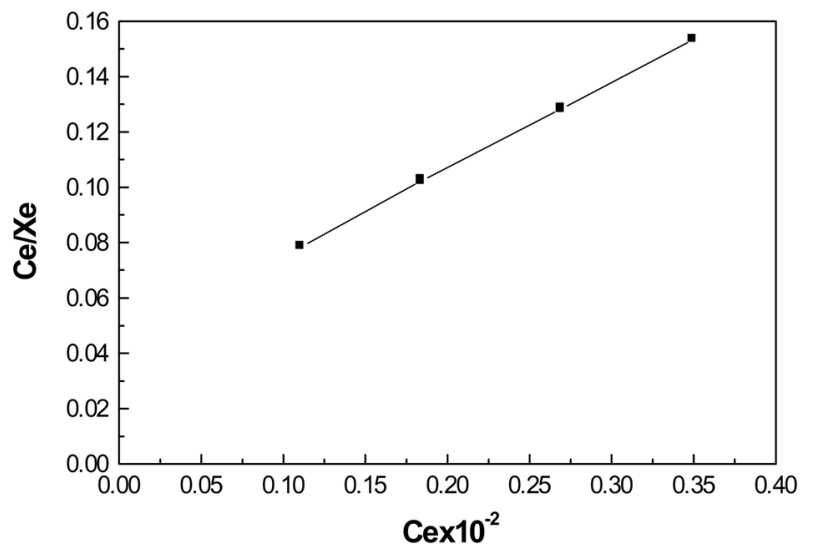

Fig. 10. Second Langmuir plot for $\mathrm{Al}^{3+}$ ions adsorption onto PAC.

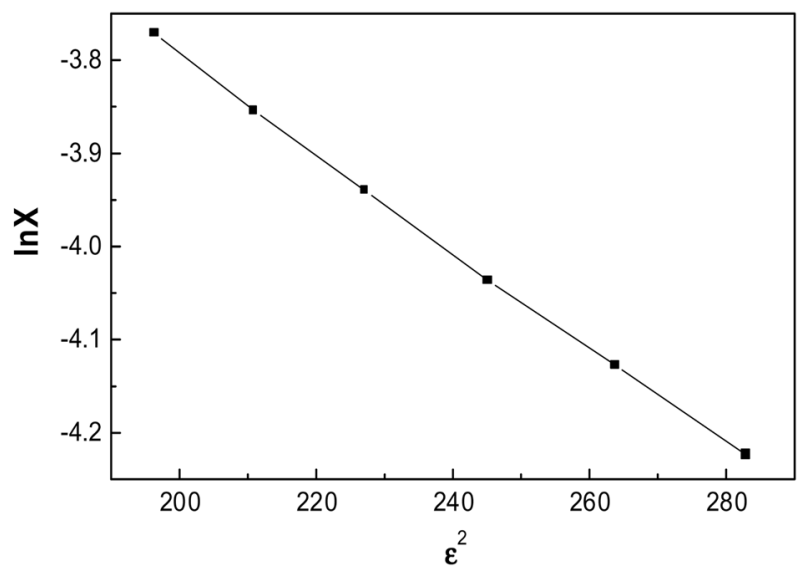

Fig. 11. Dubinin-Radushkevich (D-R) plot for $\mathrm{Al}^{3+}$ ions adsorption on to PAC. 
$\left(\mu \mathrm{g} \cdot \mathrm{L}^{-1}\right), \mathrm{X}_{\mathrm{m}}$ is the monolayer capacity $\left(\mathrm{g} \cdot \mathrm{g}^{-1}\right), \varepsilon$ is the Polanyi potential and $\beta$ is the parameter of $D-R$ isotherm with $\mathrm{X}, \mathrm{T}$ and $\mathrm{R}$ having the same meaning as above. The value of $X_{m}$ [Equation (10)] can be obtained from the slope of the plot (Fig. 10) of another Langmuir equation:

$$
\mathrm{C} / \mathrm{X}=1 / \mathrm{K}_{\mathrm{L}} \mathrm{X}_{\mathrm{m}}+\mathrm{C} / \mathrm{X}
$$

The isotherm expressed in equation (10) is more general than the Langmuir equation since it does not assume a homogeneous surface or a constant adsorption potential. Plotting of $\ln X$ versus $\varepsilon^{2}$ gave a straight line (Fig. 11) thereby indicating the applicability of the D-R equation for $\mathrm{Al}^{3+}$ ions adsorption onto PAC. From the slope and intercept of this plot, values of $\beta=-5.2 \times 10^{-3} \mathrm{~mol}^{2} / \mathrm{KJ}^{2}$ and $\mathrm{X}_{\mathrm{m}}=$ $0.0635 \mathrm{~g} \cdot \mathrm{g}^{-1}$ were obtained for aluminum adsorption. The corresponding value of the correlation coefficient (r) is 0.9995 .

The value of the adsorption energy (E) was obtained from the relationship [27, 39]:

$$
E=(-2 \beta)^{-1 / 2}
$$

The value of adsorption energy (E) was found to be 9.81 $\mathrm{kJ} \cdot \mathrm{mol}^{-1}$, indicated that a part of $\mathrm{Al}^{3+}$ ions adsorption on to

Table 2. Recovery of $\mathrm{Al}^{3+}$ ions spiked to $1 \mathrm{~L}$ of Various Water Samples Using $200 \mathrm{mg}$ of $\mathrm{PAC}$ at $\mathrm{pH} \sim 7$ and Stirring for $20 \mathrm{~min}$ at $200 \mathrm{rpm}$

\begin{tabular}{lcccc}
\hline Sample (location) & $\begin{array}{c}\mathrm{Al}(\mathrm{III}) \\
\text { added/mg }\end{array}$ & $\begin{array}{c}\mathrm{Al}(\mathrm{III}) \\
\text { found }^{\mathrm{a}} / \mathrm{mg}\end{array}$ & $\begin{array}{c}\text { Recovery, } \\
\%\end{array}$ & $\begin{array}{c}\mathrm{RSD}^{\mathrm{b}} \\
\%\end{array}$ \\
\hline Distilled water & - & $\mathrm{ND}^{\mathrm{c}}$ & - & - \\
& 1.35 & 1.34 & 99.26 & 0.45 \\
Tap water & 2.75 & 2.74 & 99.64 & 0.65 \\
(our laboratory) & - & $\mathrm{ND}^{\mathrm{c}}$ & - & - \\
& 1.35 & 1.34 & 99.26 & 0.45 \\
Nile water & 2.75 & 2.74 & 99.64 & 0.85 \\
(Mansoura City) & - & $\mathrm{ND}^{\mathrm{c}}$ & - & - \\
& 1.35 & 1.33 & 98.52 & 0.41 \\
Sea water & 2.75 & 2.73 & 99.27 & 1.12 \\
(Gamasah) & - & $\mathrm{ND}^{\mathrm{c}}$ & - & - \\
& 1.35 & 1.35 & 100.00 & 0.48 \\
(Ras El-Barr) & 2.75 & 2.74 & 99.64 & 1.21 \\
& - & $\mathrm{ND}^{\mathrm{c}}$ & - & - \\
& 1.35 & 1.33 & 98.52 & 0.50 \\
(Alexandria) & 2.75 & 2.75 & 100.00 & 1.20 \\
& - & $\mathrm{ND}^{\mathrm{c}}$ & - & - \\
& 1.35 & 1.33 & 98.52 & 0.62 \\
Lake water & 2.75 & 2.74 & 99.77 & 1.22 \\
(Manzalah) & - & $\mathrm{ND}^{\mathrm{c}}$ & - & - \\
& 1.35 & 1.33 & 98.52 & 0.41 \\
Underground water & 2.75 & 2.75 & 100.00 & 1.11 \\
(Cinbillaween City) & 1.35 & 1.35 & 100.00 & 0.50 \\
& 2.75 & 1.75 & 100.00 & 1.32 \\
\hline
\end{tabular}

${ }^{a}$ The mean of five experiments. ${ }^{b}$ Calculated for five experiments.

${ }^{\mathrm{c}} \mathrm{ND}=$ not detectable.
PAC may be physical in nature. This may be attributed to the formation of weak bonding, such as hydrogen bonding, between aluminum species $\left[\mathrm{Al}(\mathrm{OH})^{2+}\right.$ and $\left.\mathrm{Al}(\mathrm{OH})_{2}{ }^{+}\right]$and hydroxyl groups found on the active sites of PAC present as a suspension.

\subsection{Application}

To investigate the applicability of the recommended procedure, a series of experiments was performed to recover 1.35 and $2.75 \mathrm{mg}$ of $\mathrm{Al}^{3+}$ ions added to aqueous and some natural water samples. The adsorption experiments were carried out using $1 \mathrm{~L}$ of clear, filtered, uncontaminated sample solutions after adjusting their $\mathrm{pH}$ values to 7.0. The results obtained are listed in Table 2 and show that the recovery was satisfactory and quantitative (ca. 100\%). The relative standard deviations (RSD) were calculated for five replicate analyses and the maximum value does not exceed $1.22 \%$. Moreover, the recovery of $\mathrm{Al}^{3+}$ ions from brackish water samples are good, in comparison with other fresh water samples, which may be attributed to the presence of $\mathrm{Na}^{+}, \mathrm{Mg}^{2+}$ and $\mathrm{Ca}^{2+}$ ions in the former ones acting as activators [40].

\section{Conclusions}

Powdered activated carbon has been investigated as cheap and effective organic sorbent for the removal of $\mathrm{Al}^{3+}$ ions from aqueous solutions. The experimental results revealed the following:

(i) The adsorption process was endothermic and followed first-order kinetics.

(ii) It occurred mainly at the surface of the solid PAC and to some extent by the internal pores.

(iii) It was well described by the Langmuir and Freundlich models.

(iv) It could be chemical in nature since the adsorption of $\mathrm{Al}^{3+}$ ions may involve chelate formation between $\mathrm{Al}^{3+}$ ions and oxygen atoms on PAC surface.

(v) Moreover, the procedure was successfully applied to the recovery of aluminum spiked to drinking and some environmental water samples with an RSD (\%), does not exceed $1.22 \%$.

\section{References}

[1] Fasal, M.; Hasnain, S. Afr. J. Biotechnol. 2004, 3, 610.

[2] Igwe, J.; Abia, A. A. Afr. J. Biotechnol. 2006, 5, 1167.

[3] Downs, A. J., Chemistry of Aluminum, Gallium, Indium and Thalium, 1st ed.; Chapman \& Hall (London) 1993.

[4] Lindsay, W. L.; Walthall, P. M., The Environmental Chemistry of Aluminum, Sposito, G., ed., CRC Press 
(Boca Raton, Florida) 1996.

[5] Ghazy, S. E.; Samra, S. E.; Mahdy, A. M.; El-Morsy, S. M. Anal. Sci. 2003, 19, 1401.

[6] Fuse,Y.; Yamada, T.; Yamada, E. Anal. Sci. 2004, 20, 177.

[7] Yoshimura, E.; Akashi, M.; Umemura, T.; Tsunoda, K-I. Anal. Sci. 2004, 20, 373.

[8] Zatta, P.; Zambenedetti, P.; Milačič, R. Analusis Magazine 1998, 26, M72.

[9] Havens, K. E.; Heath R. T. Pollut. 1989, 62, 195.

[10] Birchall, J. D.; Exley, C.; Chappell, J. S.; Phillips, M. J. Nature 1989, 338, 146.

[11] Srinivasan, P. T.; Viraraghavan, T.; Subramanian, K. S. Water SA 1999, 25, 47.

[12] Parker, D. R.; Kinraide, T. B.; Zelazny, L. W. Soil. Sci. Soc. Am. J. 1989, 53, 789.

[13] Campbell, E.; Bisson, P. G. C.; Bougie, R.; Tessier, A.; Villeneuve, J-P. Anal. Chem. 1983, 55, 2246.

[14] Mitrović, B.; Milačič, R.; Simončičc, P. Analusis 1998, 26, 381.

[15] Miu, A. C.; Benga, O. J. Alzheimer's Disease 2006, 10, 179.

[16] Bensen, R. L.; Worsfold, P. J.; Sweeting, F. W. Anal. Chim. Acta 1990, 238, 177.

[17] Blocher, C.; Dorda, J.; Mavrov, V.; Chemiel, H.; Lazaridis, N. K.; Matis, K. A. Water Res. 2003, 37, 4018.

[18] Zouboulis, A. I.; Lazaridis, N. K.; Zamboulis, D. Sep. Sci. Technol. 1994, 29, 385.

[19] Sharma, D. C.; Forster, C. F. Water SA 1996, 22, 153.

[20] Ho, Y. S.; McKay, G. Adsorp. Sci. Technol. 1998, 16, 243.

[21] Ghazy, S. E.; Samra, S. E.; El-Morsy, S. M. Adsorp. Sci. Technol. 2001, 19, 721.

[22] Dastgheib, S. A.; Rockstraw, D. A. Carbon 2002, 40, 1853.

[23] Banat, F.; Al-Asheh, S.; Al-Makhadmeh, L. Adsorp. Sci.
Technol. 2003, 21, 245.

[24] Youssef, A. M.; El-Nabarawy, Th.; El-Shafey, E. I. Carbon Sci. 2006, 7, 1.

[25] Al-Asheh, S.; Banat, F. Adsorp. Sci. Technol. 2001, 19, 117.

[26] Yubin, T.; Fangyan, C.; Honglin, Z. Adsorp. Sci. Technol. 1998, 16, 595.

[27] Akhtar, S.; Qadeer, R. Adsorp. Sci. Technol. 1997, 15, 815.

[28] Weber, W. J. Jr.; Morris, S. C. J. Sanit. Eng. Div. Am. Soc. Civ. Eng. 1963, 89, 53.

[29] Crank, J. The Mathematics of Diffusion; Carlendon Press (Oxford, London) 1965.

[30] McKay, G.; Otterbern, M. S.; Sweeney, A. G. Water Res. 1980, $14,15$.

[31] Juang, R.; Wu, F.; Tseng, R. J. Colloid Interface Sci. 2000 , 227, 4374.

[32] Ghazy, S. E.; Ragab, A. H. Sep. Sci. Technol 2007, 42, 653.

[33] Qadeer, R.; Hanif, J. Radiochim. Acta 1994, 65, 259.

[34] Gupta, G. S.; Shukla, S. P. Adsorp. Sci. Technol. 1996, 13, 15.

[35] Khalid, N.; Ahmad, S.; Toheed, A.; Ahmed, J. Adsorp. Sci. Technol. 1998, 16, 655.

[36] Nassar, M. M.; Hamoda, M. F.; Radwan, G. H. Adsorp. Sci. Technol. 1996, 13, 1.

[37] Panday, K. K.; Prasad, G.; Singh, V. N. J. Chem. Technol. Biotechnol. 1984, 34, 367.

[38] Panday, K. K.; Prasad, G.; Singh, V. N. Water Res. 1985, 19, 869.

[39] Reichenberg, D. J. Am. Chem. Soc. 1953, 75, 589.

[40] Ghazy, S. E.; Samra, S. E.; El-Morsy, S. M. Adsorp. Sci. Technol. 2001, 19, 175. 